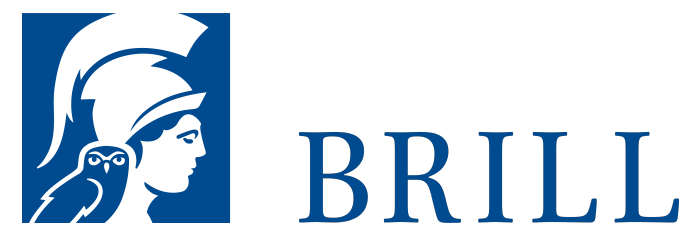

\title{
Pilger, Popen und Propheten
}

Eine Religionsgeschichte Osteuropas

Author: Christoph Schmidt

Die religiöse Vielfalt Osteuropas übertrifft die des Westens bei weitem. Das Neben- und Miteinander von Schamanen, Muslimen, Christen und Juden prägte schon das Mittelalter. Im 17. Jahrhundert kamen Buddhisten hinzu.

An der Grenze zwischen Ost- und Westkirche entstanden zudem neue Glaubensrichtungen: Die Unierte Kirche hielt an der byzantinischen Liturgie fest, erkannte aber den Papst an. Und der Chassidismus widmete sich vor allem den ekstatischen und magischen Aspekten der jüdischen Tradition. Sie alle versuchte der sowjetische Atheismus zu beseitigen, bis er am auch durch die Religion getragenen - Widerstand Polens zerbrach. Christoph Schmidt entfaltet ein eindrucksvolles Panorama des religiösen Lebens zwischen Weichsel und Wolga, führt den Leser vor mittelalterliche Ikonen, in die Schtetl der Frühen Neuzeit, in die Jurten der buddhistischen Kalmüken, aber auch zu den Moscheen der Tataren-Metropole Kazan, die seit Jahrhunderten Zentrum des russischen Islam ist.

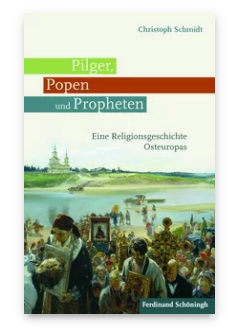

Pages: 293

Seiten, $4 \mathrm{~s} / \mathrm{w}$ und 6 farb. Abb.

Language:

German

Subjects: Global History, History

Publisher: Brill |

Schöningh

E-Book (PDF)

Released online: o6 May 2014 ISBN: 978-3657-77265-0 
Biographical Note

Christoph Schmidt, Prof. Dr. phil., lehrt Osteuropäische Geschichte an der Universität Köln.

For more information see brill.com

\begin{abstract}
Order information: Order online at brill.com +44330 333 0049 | customerservices@brill.com Submission information: brill.com/authors
\end{abstract}

Titles published by Brill | Fink, Brill | mentis or Brill| Schöningh: +49(o)71 5413279216 | brill@brocom.de 